\title{
Convolvulaceae da Microrregião do Alto Capibaribe, PE, Brasil
}

\author{
Silmara Cecília Nepomuceno ${ }^{1,2}$, Sarah Maria Athiê-Souza ${ }^{1}$ e Maria Teresa Buril ${ }^{1}$
}

Recebido: 3.05.2016; aceito: 14.06.2016

\begin{abstract}
Convolvulaceae from the Microregion of Alto Capibaribe, Pernambuco State, Brazil). Convolvulaceae is a widely distributed family, most diverse in the Neotropics. 19 genera and 209 species occur in Northeastern Brazil, where this family has only recently been studied. The present study aims to increase the knowledge about Convolvulaceae in the region, focusing on the Microregion of Alto Capibaribe, Pernambuco State. Twenty species of the following genera are found in the area: Evolvulus (two species), Ipomoea (eight), Jacquemontia (five), Merremia (three), Operculina (one), and Turbina (one). Half of the species are new records to the area. Descriptions, taxonomic and distribution notes, illustrations, and a key for identification are presented.
\end{abstract}

Keywords: Floristics, Ipomoea, taxonomy, vines

RESUMO - (Convolvulaceae da Microrregião do Alto Capibaribe, PE, Brasil). Convolvulaceae apresenta distribuição cosmopolita com maior diversidade nos Neotrópicos. No Nordeste do Brasil, onde os estudos sobre a família são recentes, são encontrados 18 gêneros e 209 espécies. Sendo assim, este trabalho objetivou ampliar os estudos de Convolvulaceae na região, enfocando a microrregião do Alto Capibaribe em Pernambuco. A família é representada na área por 20 espécies incluídas nos gêneros Evolvulus (duas spp.), Ipomoea (oito spp.), Jacquemontia (cinco spp.), Merremia (três spp.), Operculina (uma sp.) e Turbina (uma sp.). Metade das espécies são novos registros para área. São apresentadas descrições, comentários taxonômicos e de distribuição, ilustrações e uma chave de identificação.

Palavras-chave: Florística, Ipomoea, taxonomia, trepadeiras

\section{Introdução}

Convolvulaceae compreende 58 gêneros e cerca de 1.880 espécies (Staples 2012) encontradas por todo o globo, mas predominantemente diversas nos neotrópicos (Mabberley 1987, Austin 1998, Staples \& Brummitt 2007). Para o Brasil são reportadas 401 espécies em 21 gêneros as quais podem ser encontradas em todos os Estados e domínios fitogeográficos (BFG 2015). Ocorrem principalmente em fitofisionomia de savana e para o Nordeste do Brasil são registradas mais de $50 \%$ das espécies conhecidas no país (209 espécies em 18 gêneros).

As convolvuláceas são geralmente trepadeiras, arbustos, ervas, raramente holoparasitas (Cuscuta L.), com folhas geralmente simples, alternas, sem estípulas, com inflorescências cimosas, flores bissexuadas, diclamídeas, actinomorfas, cálice e corola 5-mero, sépalas livres, corola gamopétala com prefloração convoluta, isostêmones, com estames assimétricos e epipétalos e anteras com deiscência longitudinal, ovário súpero, bicarpelar e bilocular, contendo um ou dois óvulos por lóculo, estilete terminal e placentação axial ou ereta (Austin 2004, Souza \& Lorenzi 2005).

Diversas espécies da família destacam-se pelo potencial econômico. Ipomoea batatas (L.) Lam. (batata-doce) é amplamente consumida na África e América do Sul (Silva \& Simão-Bianchini 2012). Espécies de Cuscuta são holoparasitas de plantas cultivadas, ornamentais, silvestres e de outras plantas daninhas latifoliadas (Pereira 1998). Ipomoea asarifolia (Desr.) Roem. \& Schult. e I. carnea Jacq. são tóxicas para os animais (Chaves 2009, Gotardo 2009). Embora ainda pouco explorado no Brasil, diversas espécies possuem potencial ornamental (Simão-Bianchini 1998).

No Nordeste, os estudos com a família têm se intensificado a partir de 2011, com a publicação da Flora da Usina São José (Buril \& Alves 2011a), dos Cariris Paraibanos (Buril et al. 2013) e do Parque Nacional Vale do Catimbau (Delgado et al. 2014).

1. Universidade Federal Rural de Pernambuco, Departamento de Biologia, Área de Botânica, 52171-900 Recife, PE, Brasil

2. Autor para correspondência: silmaracnepomuceno@gmail.com 
Estes trabalhos revelaram que o número de espécies encontradas nestas localidades era o dobro do que se conhecia previamente a partir de levantamentos florísticos. É ainda importante destacar que com o aumento de especialistas na família nos últimos anos, a descoberta de novas espécies foi ampliada, e muitas destas são endêmicas ou ocorrem no Nordeste. Três espécies de Evolvulus foram descritas por Silva \& Simão-Bianchini (2014), e entre 2011 e 2013 foram publicadas seis novas espécies de Jacquemontia (Buril \& Alves 2011b, Buril \& Alves 2012a, b, Buril et al. 2012, Buril \& Alves 2013). Várias destas espécies já foram descritas sob o status de vulneráveis ou ameaçadas de extinção.

Apesar do recente esforço em melhorar o conhecimento da família nesta região do país, algumas regiões ainda carecem de informações. Em poucos anos, várias espécies novas de Convolvulaceae foram descritas, demonstrando que essa região merece atenção especial, e deve ser mais estudada. Sendo assim, este trabalho teve como objetivo, ampliar os estudos da família no Nordeste brasileiro, com ênfase na microrregião do Alto Capibaribe, uma área de ecótono entre Caatinga e Mata Atlântica.

\section{Materiais e métodos}

Área de estudo - O estudo foi realizado no período de julho de 2014 a junho de 2015 nos municípios de Santa Cruz do Capibaribe, Taquaritinga do Norte e Vertentes, os quais situam-se na microrregião do Alto Capibaribe. Essa área está inserida no agreste de Pernambuco, especificamente no Planalto da Borborema e compreende também os municípios de Casinhas, Frei Miguelinho, Santa Maria do Cambucá, Surubim, Toritama e Vertentes do Lério (CONDEPE/ FIDEM 2006). A microrregião ocupa uma área com relevo ondulado a forte ondulado e, algumas vezes constituído por vales profundos e estreitos. O clima enquadra-se no tipo BSh, ou seja, semiárido quente e seco, segundo a classificação de Köppen (Andrade
\& Lins 1965) com temperatura média de $25{ }^{\circ} \mathrm{C}$. As chuvas são mal distribuídas ao longo do ano e se concentram no período de fevereiro a março com precipitação pluviométrica anual média em torno de 431,8 - 648,7 mm. A vegetação é representada, predominantemente, por Caatinga hiperxerófila, com trechos de florestas subcaducifólias e caducifólias (CPRM 2005).

Levantamento de dados - O presente trabalho foi baseado na análise das coleções depositadas nos herbários HST, HUEFS, HVASF, IPA, JPB, NY, PEUFR e UEC (acrônimos segundo Index Herbariorum, http://sweetgum.nybg.org/ih/), sendo o material do NY consultado através de imagens de alta definição e as demais presencialmente, e na observação de populações em campo, seguindo os métodos usuais em taxonomia vegetal para as coletas e herborização do material (Mori et al. 1985). Os vouchers coletados foram depositados no Herbário PEUFR, com duplicatas encaminhadas para os herbários SP e K. A identificação foi baseada na comparação com materiais previamente identificados, coleções-tipo quando disponíveis on-line, e na consulta à bibliografia especializada (Simão-Bianchini 1998, Buril \& Alves 2011a, Buril et al. 2013, Delgado et al. 2014). A terminologia adotada é a proposta por Harris \& Harris 2001.

\section{Resultados e Discussão}

$\mathrm{Na}$ microrregião do Alto Capibaribe (PE) foram registradas 20 espécies de Convolvulaceae distribuídas em cinco gêneros (Evolvulus, Ipomoea, Jacquemontia, Merremia e Turbina). Ipomoea foi o gênero mais diverso contendo oito espécies, seguido de Jacquemontia (cinco spp.), Merremia (três spp.), Evolvulus (duas spp.) e Operculina e Turbina com apenas uma espécie cada. Essas espécies foram encontradas em áreas de Caatinga hiperxerófila a hipoxerófila e em Brejo de Altitude, a maioria associada a ambientes antropizados.

\section{Chave de Identificação das Espécies de Convolvulaceae Ocorrentes na Microrregião} do Alto Capibaribe, Pernambuco

\section{Folhas compostas, digitadas}

2. Pecíolos alados; corola $>6 \mathrm{~cm}$ compr.

19. Operculina macrocarpa

2. Pecíolos não alados; corola $<5 \mathrm{~cm}$ compr.

3. Folhas glabras; cálice com sépalas acrescentes 18. Merremia macrocalyx

3. Folhas glabrescentes, ciliadas a pubescentes; cálice não acrescente

4. Folhas com margem denteada; cálice pubescente; corola com fauce do tubo vinácea ... 17. Merremia cissoides

4. Folhas com margem discretamente sinuosa; cálice hirsuto; corola branca 16. Merremia aegyptia 
1. Folhas simples, inteiras a lobadas

5. Subarbustos prostrados ou eretos a arbustos

6. Folhas até $1,4 \mathrm{~cm}$ compr.

7. Inflorescência em glomérulo congesto; indumento das folhas velutino

2. Evolvulus glomeratus

7. Inflorescência com flores solitárias, indumento das folhas pubescente 1. Evolvulus filipes

6. Folhas a partir de $2,5 \mathrm{~cm}$ compr.

8. Subarbusto prostrado; folhas reniformes

4. Ipomoea asarifolia

8. Arbusto ereto; folhas lanceoladas

6. Ipomoea carnea

5. Trepadeiras herbáceas a lianas

9. Ramos aculeados

9. Ipomoea parasitica

9. Ramos inermes

10. Ramos com tricomas estrelados

11. Sépalas com ápice arredondado

14. Jacquemontia nodiflora

11. Sépalas com ápice agudo a acuminado

12. Sépalas glabras, ápice reflexo

13. Jacquemontia martii

12. Sépalas com indumento, ápice reto

13. Folhas pubescentes

15. Jacquemontia pentanthos

13. Folhas velutinas

14. Bractéolas lineares

11. Jacquemontia corymbulosa

14. Bractéolas setosas

12. Jacquemontia mucronifera

10. Ramos com tricomas simples

15. Sépalas com indumento denso, hirsutos, velutinas a tomentosas, nunca ciliadas

16. Cálice hirsuto

8. Ipomoea nil

16. Cálice velutino a tomentoso

17. Corola hipocrateriforme, sépalas externas repandas

10. Ipomoea tubata

17. Corola infundibuliforme, sépalas externas inteiras

20. Turbina cordata

15. Sépalas glabras a glabrescentes, raro ciliadas

18. Cálice liso

7. Ipomoea grandifolia

18. Cálice verrucoso ou rostrado

19. Folhas glabras, ovadas; sépalas internas lisas

3. Ipomoea aristolochiifolia

19. Folhas ciliadas, glabrescentes, lanceoladas; sépalas rostradas

5. Ipomoea bahiensis

Evolvulus L., Species Plantarum 1 391. 1762.

Subarbustos eretos de $30 \mathrm{~cm}$ a $40 \mathrm{~cm}$ de alt. Ramos inermes, pubescentes, tricomas simples. Folhas simples, inteiras, pubescentes a velutinas. Inflorescência em flores solitárias ou glomérulos congestos. Flores com pedicelos ausentes a $5 \mathrm{~mm}$ compr., sépalas não acrescentes, iguais entre si, pubescentes. Corola rotácea, azul ou branca. Estames de tamanhos diferentes, 2,5-6 $\mathrm{mm}$ compr., anteras retas após antese. Estilete bífido, estigmas 2, filiformes. Fruto cápsula.

1. Evolvulus filipes Mart., Flora 24 (2, Beibl.): 100. 1841.

Figura 1a

Subarbustos eretos, ca. $30 \mathrm{~cm}$ alt. Ramos pubescentes, tricomas simples, entrenós $0,3-1 \mathrm{~cm}$ compr. Látex ausente. Folhas simples, lanceolada,
0,2-2,3 × 0,2-0,7 cm, base cuneada, ápice cuspidado a obtuso, margem inteira, pubescentes em ambas as faces, concolores, veias secundárias não perceptíveis, pecíolo 0-1 $\mathrm{mm}$ compr. Inflorescência uniflora, pedúnculo 1-4 cm, bractéolas lineares, ca. 1-2 mm compr., pubescentes, pedicelo 1-5 mm compr. Cálice com sépalas iguais entre si, lanceoladas, ca. $4 \times 0,7 \mathrm{~mm}$, pubescentes, ápice acuminado, lisas, não acrescentes. Corola ca. $4 \mathrm{~mm}$ compr., glabra, branca. Estames ca. 2,5 mm compr., anteras $1 \mathrm{~mm}$ compr. Estilete ca. $1 \mathrm{~mm}$ compr. Fruto globoso, seco indeiscente, ca. $3 \mathrm{~mm}$ compr. Sementes glabras, ca. $1 \mathrm{~mm}$ compr.

Material examinado: BRASIL. PeRnAmBuco: Surubim, 16-X-1941, L.P. Xavier JPB375 (JPB).

Material adicional: BRASIL. Pernambuco: Fazenda Nova, 19-VI-1997, M.B. Costa e Silva 1214 (PEUFR); Caruaru, 18-IV-1997, V. Santos 7 (PEUFR). 


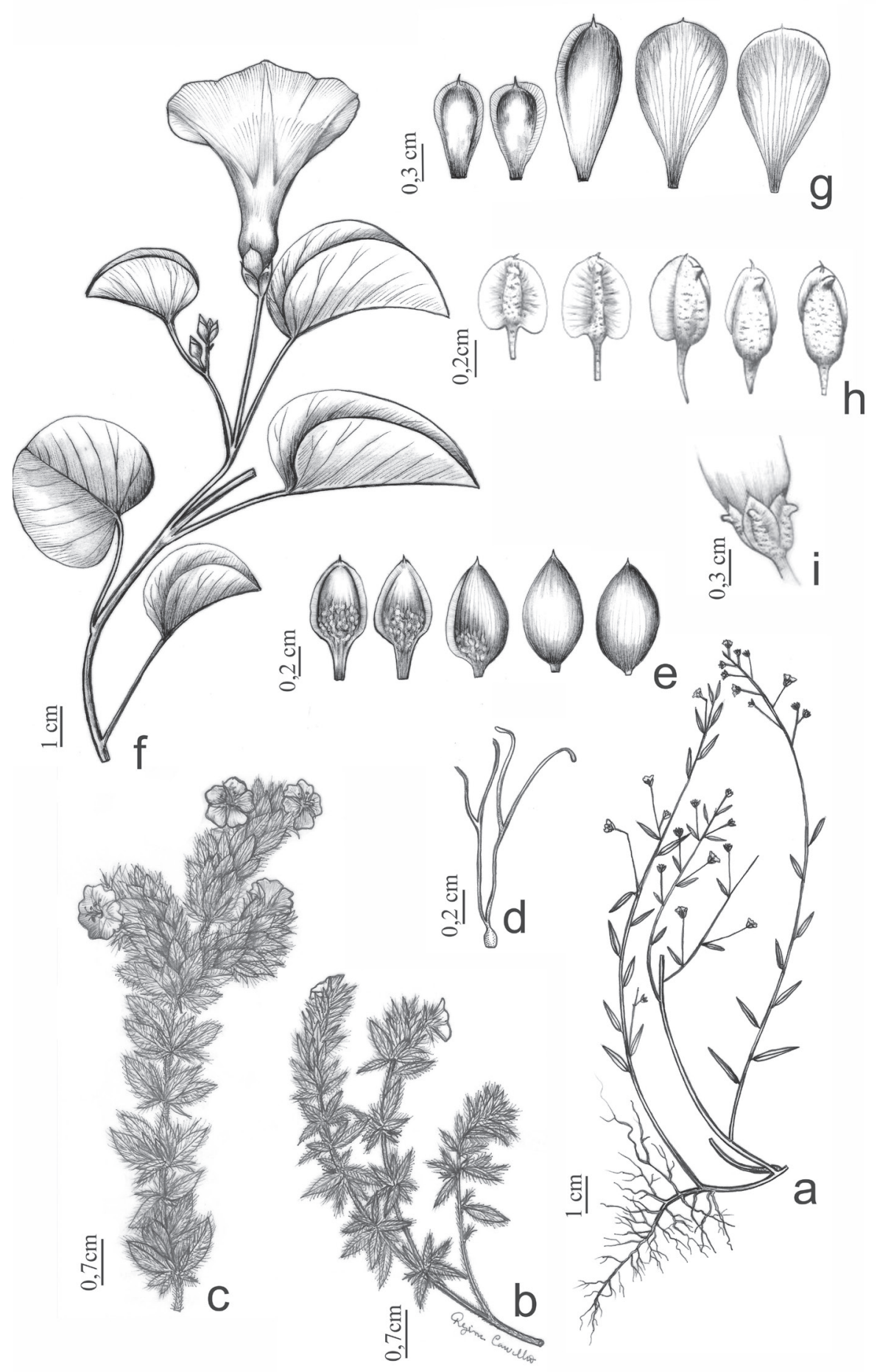

Figura 1. a. Evolvulus filipes. Ramo fértil. b-d. Evolvulus glomeratus. b-c. Ramo fértil. d. Estiletes bífidos. e. Ipomoea aristolochiifolia. Sépalas externas à esquerda e internas à direita. f-g. Ipomoea asarifolia. f. Ramo fértil. g. Sépalas externas à esquerda e internas à direita. h-i. Ipomoea bahiensis. h. Sépalas externas à esquerda e internas à direita. i. Vista lateral do cálice.

Figure 1. a. Evolvulus filipes. Fertile branch. b-d. Evolvulus glomeratus. b-c. Fertile branch. d. Bifid styles. e. Ipomoea aristolochiifolia. Outer sepals (left), inner sepals (right). f-g. Ipomoea asarifolia. f. Fertile branch. g. Outer sepals (left), inner sepals (right). h-i. Ipomoea bahiensis. h. Outer sepals (left), inner sepals (right). i. Lateral view of calyx. 
Ocorre desde a América Central ao Paraguai. No Brasil é amplamente distribuída, não ocorrendo apenas nos Estados do Acre, Amapá, Rondônia, Santa Catarina e Rio Grande do Sul (BFG 2015). É facilmente reconhecida pelo hábito ereto e flores diminutas (cerca de $4 \mathrm{~mm}$ ).

2. Evolvulus glomeratus Nees \& C. Mart., Novorum Actorum Academiae Caesareae LeopoldinaeCarolinae Naturae Curiosorum 11(1): 81. 1823. Figuras 1b-d

Subarbustos eretos, ca. $40 \mathrm{~cm}$ alt. Ramos pubescentes, tricomas simples, entrenós $0,1-2 \mathrm{~cm}$ compr. Látex ausente. Folhas simples, ovadas, 2-7 $\times 3-14 \mathrm{~mm}$, base cuneada, ápice cuspidado a obtuso, margem inteira, velutino em ambas as faces, concolores, veias secundárias não perceptíveis, pecíolo 0-1 mm compr. Inflorescência em glomérulos congestos, pedúnculo ausente, bractéolas lanceoladas, ca. $5 \mathrm{~mm}$ compr., pubescentes, pedicelo ausente. Cálice com sépalas iguais entre si, lanceoladas, ca. $1 \times 1-5 \mathrm{~mm}$, pubescentes, ápice arredondado, lisas, não acrescentes. Corola ca. $1 \mathrm{~cm}$ compr., glabra, azul. Estames ca. $6 \mathrm{~mm}$ compr., anteras $1 \mathrm{~mm}$ compr. Estilete ca. $8 \mathrm{~mm}$ compr. Fruto globoso, seco indeiscente, ca. 0,3 cm compr. Sementes glabras, ca. 1,5 mm compr.

Material examinado: BRASIL. Pernambuco: Taquaritinga do Norte, 25-IX-2014, M.T. Buril 1067 (PEUFR); Taquaritinga do Norte, 25-IX-2014, M.T. Buril 1069 (PEUFR).

A espécie é amplamente distribuída por todo o Brasil, não havendo registros de ocorrência apenas nos Estados do Amapá e Tocantins (BFG 2015). $\mathrm{Na}$ microrregião do Alto Capibaribe foi coletada no município de Taquaritinga do Norte, em área de transição entre Caatinga e Brejo de Altitude e, em afloramentos rochosos. Diferencia-se pelas inflorescências em glomérulos congestos.

Ipomoea L., Species Plantarum 1: 159. 1753.

Trepadeiras herbáceas, lianas, arbustos prostrados ou eretos. Ramos glabros a pubescentes, tricomas simples, raro aculeados. Folhas inteiras a trilobadas, glabras ou pubescentes, com indumento variado. Inflorescência, em geral, cimeira dicasial, raro umbeliforme, corimbulosa ou monocasial, 2-11 flora. Flores pediceladas, sépalas não acrescentes, iguais ou desiguais, glabras ou pubescentes, indumento variável, tricomas simples, lisas, raramente rostradas ou verrucosas. Corola infundibuliforme, raro hipocrateriforme, rósea ou lilás, raramente azul ou branca. Estames de tamanhos diferentes, anteras retas após antese. Estilete inteiro, estigmas 2, globosos. Fruto cápsula geralmente globoso. Sementes de glabrescentes a velutinas.

3. Ipomoea aristolochiifolia G. Don., A General History of the Dichlamydeous Plants 4: 277. 1838. Figura 1e

Trepadeira herbácea. Ramos glabros, inermes, sulcados, entrenós 3,5-10,5 $\mathrm{cm}$ compr. Látex ausente. Folhas ovadas, 4,3-8,1 × 4,3-8,7 cm, base cordada, ápice acuminado, margem discretamente sinuosa, glabras, levemente discolores com face adaxial mais escura, 6-7 pares de veias secundárias, pecíolo 2,8-10,3 cm compr. Inflorescência cimeira, 2-3-flora, pedúnculo 1,4-3,8 cm compr., bractéolas ausentes, pedicelo 4-8 $\mathrm{mm}$ compr. Cálice com sépalas desiguais, externas lanceoladas, ca. $6 \times 4 \mathrm{~mm}$, glabras, ápice acuminado, verrucosas, internas obovadas, ca. $8 \times 4 \mathrm{~mm}$, glabras, ápice agudo, lisas. Corola infundibuliforme, 1,7-2,7 cm compr., glabra, rosa. Estames 1-1,5 cm compr., anteras 1-2 mm compr. Estilete 1,2-1,3 cm compr. Fruto globoso, ca. $7 \mathrm{~mm}$ compr. Sementes glabrescentes, ca. $5 \mathrm{~mm}$ compr.

Material examinado: BRASIL. Pernambuco: Santa Cruz do Capibaribe, 25-IX-2014, M.T. Buril 1074 (PEUFR).

É largamente distribuída nas Américas ocorrendo desde o México até o Peru (Austin \& Huaman 1996). No Brasil ocorre em todas as regiões, entretanto, no Norte, há registro apenas no Estado do Pará (BFG 2015). Pouco frequente na área de estudo, a espécie foi coletada no munícipio de Santa Cruz do Capibaribe em área antropizada e pode ser identificada principalmente por suas sépalas verrucosas.

4. Ipomoea asarifolia (Desr.) Roem. \& Schult., Systema Vegetabilium 4: 251. 1819.

Figuras 1f-g

Subarbusto prostrado. Ramos glabros, inermes, entrenós 1,5-8 cm compr. Látex leitoso. Folhas reniformes, $3,8-7,7 \times 2,8-8,2 \mathrm{~cm}$, base cordada a auriculada, ápice obtuso, margem inteira, glabras, discolores com face adaxial mais escura; 8-9 pares de veias secundárias, pecíolo $1,7-5,6 \mathrm{~cm}$ compr. Inflorescência cimeira monocasial, 2-8-flora, pedúnculo 2,1-4,9 cm compr., bractéolas lanceoladas, $1-1,7 \times 0,5-0,9 \mathrm{~cm}$, glabras, pedicelo $0,9-1,2 \mathrm{~cm}$ 
compr. Cálice com sépalas desiguais, externas obovadas, ca. $9 \times 4 \mathrm{~mm}$, glabras, ápice obtuso, lisas, internas espatuladas a obovadas, $1,5 \times 0,8 \mathrm{~cm}$, glabras, ápice redondo, lisas. Corola infundibuliforme, 5,2-6,7 cm compr., glabra, rosa. Estames 2,2-3,5 cm compr., anteras 5-7 mm compr. Estilete 2,1-2,4 cm compr. Fruto globoso, ca. $1 \mathrm{~cm}$ compr. Sementes não vistas.

Material examinado: BRASIL. Pernambuco: Santa Cruz do Capibaribe, 25-IX-2014, M.T. Buril 1060 (PEUFR).

\section{Material adicBFG(PEUFR).}

Espécie amplamente distribuída nas Américas, ocorrendo desde o Panamá até o Paraguai (Austin \& Huaman 1996). No Brasil, é citada com frequência desde a região Norte ao Rio de Janeiro (BFG 2015). Na região do Alto Capibaribe foi encontrada no município de Santa Cruz do Capibaribe em área antropizada. É facilmente identificada devido ao hábito prostrado e as folhas reniformes.

5. Ipomoea bahiensis Willd. ex Roem. \& Schult., Systema Vegetabilium 4: 789. 1819.

Figuras 1h-i

Trepadeira herbácea. Ramos glabros, inermes, entrenós 3-15,5 cm compr. Látex ausente. Folhas lanceoladas, 4,7-11,8 × 1-3,2 cm, base sagitada, raro cordada, ápice acuminado com múcron, margem ciliada discretamente sinuosa a inteira, glabrescentes na face abaxial, face adaxial com tricomas apenas nas nervuras, discolores com face adaxial mais escura, 6-8 pares de veias secundárias, pecíolo 1,5-6 cm compr. Inflorescência cimeira dicasial, 4-11-flora, pedúnculo 1,5-12 cm compr., bractéolas lanceoladas, ca. 1,5-4 mm compr., pubescentes, pedicelo $0,5-1 \mathrm{~cm}$ compr. Cálice com sépalas desiguais, externas elípticas, ca. $7 \times 4 \mathrm{~mm}$, glabras, ápice agudo, rostrada, com pontos pretos, internas cordadas, $7 \times 2 \mathrm{~mm}$, glabras, ápice obtuso, rostradas. Corola infundibuliforme, ca. $4 \mathrm{~cm}$ compr., glabra, lilás. Estames 1,3-1,8 cm compr., anteras 2-3 cm compr. Estilete ca. $2 \mathrm{~cm}$ compr. Fruto globoso, ca. $5 \mathrm{~mm}$ compr. Sementes velutinas, ca. $4 \mathrm{~mm}$ compr.

Material examinado: BRASIL. Pernambuco: Taquaritinga do Norte, 25-IX-2014, M.T. Buril 1059 (PEUFR); Taquaritinga do Norte, 25-IX-2014, M.T. Buril 1063 (PEUFR).
A espécie é endêmica do Brasil (Austin \& Huaman 1996) e ocorre desde a região Norte ao Sudeste do País (BFG 2015). Encontrada com frequência na região do Alto Capibaribe, desde áreas bem preservadas a áreas antropizadas. É facilmente reconhecida por suas sépalas rostradas.

6. Ipomoea carnea Jacq., Enumeratio Systematica Plantarum, quas in insulis Caribaeis 13. 1760.

Figuras 2a-c

Arbusto ereto, ca. 1,5 m de altura. Ramos glabrescentes a pubescentes, inermes, entrenós 2-7 cm compr. Látex ausente. Folhas lanceoladas, $11,5-12,5 \times 2,5-5 \mathrm{~cm}$, base cordada, ápice acuminado, margem inteira, pubescentes a glabras, discolores com face adaxial levemente mais escura, ca. 9 pares de veias secundárias, pecíolo 3,5-5,5 cm compr. Inflorescência cimeira dicasial, ca. 6-flora, pedúnculo 1,5-7 cm compr., bractéolas ausentes, pedicelo 0,5-2 cm compr. Cálice com sépalas iguais, redondas, ca. 0,7 $\times 0,7 \mathrm{~cm}$, pilosas, ápice arredondado, lisas. Corola infundibuliforme, ca. $6,5 \mathrm{~cm}$ compr., pubescente, rosa. Estame não observado. Estilete ca. $3 \mathrm{~cm}$ compr. Frutos e sementes não observados.

Material examinado: BRASIL. PernAmBuco: Vertentes, 1-I-2000, L.P. Xavier s.n. (JPB439).

Material adicional: BRASIL. Pernambuco: Brejo da Madre de Deus, 11-VI-1998, V. Santos 122 (PEUFR).

Nas Américas ocorre principalmente na costa oeste, desde os Estados Unidos até o Peru (Austin \& Huaman 1996). Amplamente distribuída por todo Brasil, só não há registro da espécie no Estado de Rondônia (BFG 2015). Na área de estudo, é mencionada para os municípios de Taquaritinga do Norte (Caatinga) e Vertentes. Diferencia-se das demais espécies de Convolvulaceae nesta área por apresentar hábito arbustivo ereto.

7. Ipomoea grandifolia (Dammer) O'Donell, Arquivos do Museu Paranaense 9: 222. 1952

Figuras 2d-e

Trepadeira herbácea. Ramos pubescentes, inermes, entrenós 5-14 cm compr. Látex ausente. Folhas trilobadas, ca. $5 \times 4,5 \mathrm{~cm}$, base cordada, ápice acuminado, margem discretamente sinuosa, glabrescentes em ambas faces, discolores com face adaxial mais escura, 8-9 pares de veias secundárias, pecíolo 3,1-8,1 cm compr. Inflorescência cimeira corimbiforme, 3-6-flora, pedúnculo 2,5-11 cm compr., 


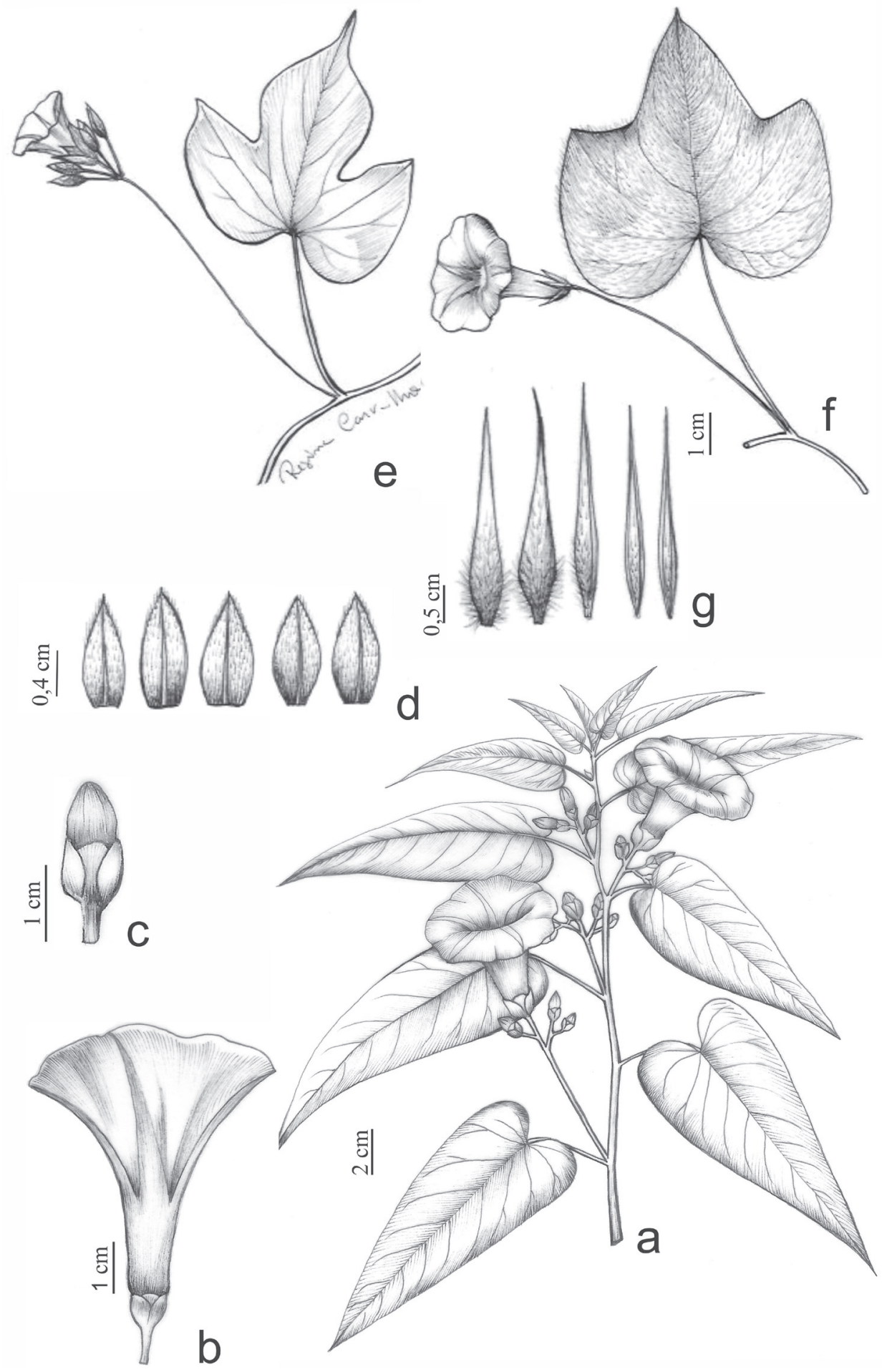

Figura 2. a-c. Ipomoea carnea. a. Ramo fértil. b. Flor. c. Botão. d-e. Ipomoea grandifolia. d. Sépalas externas à esquerda e internas à direita. e. Ramo fértil. f-g. Ipomoea nil. f. Ramo fértil. g. Sépalas externas à esquerda e internas à direita.

Figure 2. a-c. Ipomoea carnea. a. Fertile branch. b. Flower. c. Bud. d-e. Ipomoea grandifolia. d. Outer sepals (left), inner sepals (right). e. Fertile branch. f-g. Ipomoea nil. f. Fertile branch. g. Outer sepals (left), inner sepals (right). 
bractéolas lineares, ca. $4 \mathrm{~mm}$ compr., pubescentes, pedicelo 3-9 mm compr. Cálice com sépalas iguais, lanceoladas, ca. $1 \mathrm{~cm}$, pubescentes, ápice acuminado, lisas. Corola infundibuliforme, 1,5-2 cm compr., glabra, branca com centro roxo. Estames 1-1,2 cm compr., anteras 1-1,5 mm compr. Estilete ca. $1 \mathrm{~cm}$ compr. Fruto globoso, ca. $8 \mathrm{~mm}$ compr. Sementes hirsutas, ca. $4 \mathrm{~mm}$ compr.

Material examinado: BRASIL. Pernambuco: Taquaritinga do Norte, 25-IX-2014, M.T. Buril 1058 (PEUFR).

Pode ser encontrada desde os Estados Unidos até o Peru (Austin \& Huaman 1996). No Brasil, é amplamente distribuída, ocorrendo em quase todos os Estados, com exceção de Alagoas, Amapá, Maranhão, Pará e Sergipe (BFG 2015). Na região alvo deste estudo, foi encontrada em área com baixa atividade antrópica. Pode ser reconhecida, geralmente, por apresentar folhas trilobadas e sépalas pubescentes.

8. Ipomoea nil (L.) Roth, Catalecta Botanica 1: 36. 1797.

Figuras 2f-g

Trepadeira herbácea. Ramos pubescentes, inermes, entrenós 13,5-21 cm compr. Látex ausente. Folhas ovadas, inteiras a 3-lobadas, 3,5-8 ×3,5-7,5 cm, base cordada, ápice acuminado a cuspidado, margem discretamente sinuosa, pubescentes, face abaxial com tricomas adensados nas nervuras, hirsutos, discolores com face adaxial escura, 6-7 pares de veias secundárias, pecíolo 2-6,2 cm compr. Inflorescência cimeira dicasial, 3-5-flora, pedúnculo 3-8 cm compr., bractéolas lineares, 3-7 mm compr., hirsutas, pedicelo 0,3-2,6 cm compr. Cálice com sépalas subiguais, externas lanceoladas, $2,5 \times 0,2 \mathrm{~cm}$, hirsutas, ápice longo acuminado, lisas, internas lineares, $2 \times 0,3 \mathrm{~cm}$, hirsutas, ápice longo acuminado, lisas. Corola infundibuliforme, 3,5-4 cm compr., glabra, azulada com a fauce do tubo branca ou raramente branca. Estames 2,1-2,7 cm compr., anteras ca. $1 \mathrm{~mm}$ compr. Estilete ca. 2,2 cm compr. Fruto globoso ca. $0,7 \mathrm{~cm}$ compr. Sementes não vistas.

Material examinado: BRASIL. Pernambuco: Taquaritinga do Norte, 25-IX-2014, M.T. Buril 1061 (PEUFR); Taquaritinga do Norte, 25-IX-2014, M.T. Buril 1065 (PEUFR); Santa Cruz do Capibaribe, 25-IX-2014, M.T. Buril 1073 (PEUFR).

Material adicional: BRASIL. Pernambuco: Afrânio, 21-IV-1971, E.P. Heringer et al. 2014 (PEUFR).
Ocorre em todo continente Americano, desde os Estados Unidos até a Argentina (Austin \& Huaman 1996). No Brasil é amplamente distribuída e referida em todas as regiões do país, excetuando-se os estados do Amapá e Roraima. Na região estudada foram coletadas em centros urbanos e em áreas com baixo impacto antrópico. Ipomoea nil pode ser identificada por suas sépalas longo-acuminadas, hirsutas e suas corolas, na maioria das vezes, azuladas com a fauce do tubo branca.

9. Ipomoea parasitica (Kunth) G. Don., A General History of the Dichlamydeous Plants 4: 275. 1838. Figuras 3a-c

Liana. Ramos glabrescentes, aculeados, entrenós 11-21 cm compr. Látex ausente. Folhas ovadas, 7,5-17 × 6,5-16,8 cm, base cordada, ápice acuminado, margem discretamente sinuosa a ondulada, glabrescentes na face adaxial e glabras na face abaxial, discolores com face adaxial mais escura, 9-10 pares de veias secundárias, pecíolo 5-20 cm compr. Inflorescência cimeira umbeliforme, 2-4-flora, pedúnculo 1,5-12 cm compr., bractéolas lineares, ca. 0,4 cm compr., glabras, pedicelo $1-3 \mathrm{~cm}$ compr. Cálice com sépalas subiguais, externas ovadas, ca. $7 \times 5 \mathrm{~mm}$, glabras, ápice acuminado mucronado, rugosas, internas ovadas a rotundas, ca. $7 \times 6 \mathrm{~mm}$, glabras, ápice acuminado mucronado, lisas. Corola infundibuliforme 4,5-5 cm compr., pubescentes, azulada. Estames 2,4-2,8 cm compr., anteras 2-3 mm compr. Estilete ca. 1,9 cm compr. Fruto globoso, ca. $2 \mathrm{~cm}$ compr. Sementes pubescentes, ca. $0,9 \mathrm{~cm}$ compr.

Material examinado: BRASIL. Pernambuco: Taquaritinga do Norte, 25-IX-2014, M.T. Buril 1057 (PEUFR).

Espécie registrada nas Américas, com predominância na América Central (Austin \& Huaman 1996). No Brasil, ocorre nas regiões Nordeste, CentroOeste e Sudeste, desde o Maranhão até Minas Gerais em áreas de Caatinga, Cerrado e Mata Atlântica (BFG 2015). Na microrregião do Alto Capibaribe foi encontrada em áreas de Brejo, podendo ser facilmente reconhecida por ser a única com ramos aculeados.

10. Ipomoea tubata Nees, Flora 4: 301.1821.

Figuras 3d-e

Liana. Ramos pubescentes, inermes, entrenós 3,5-8 cm compr. Látex não observado. Folhas ovadas, 1,5-6 × 3-9 cm, base cordada, ápice acuminado, 

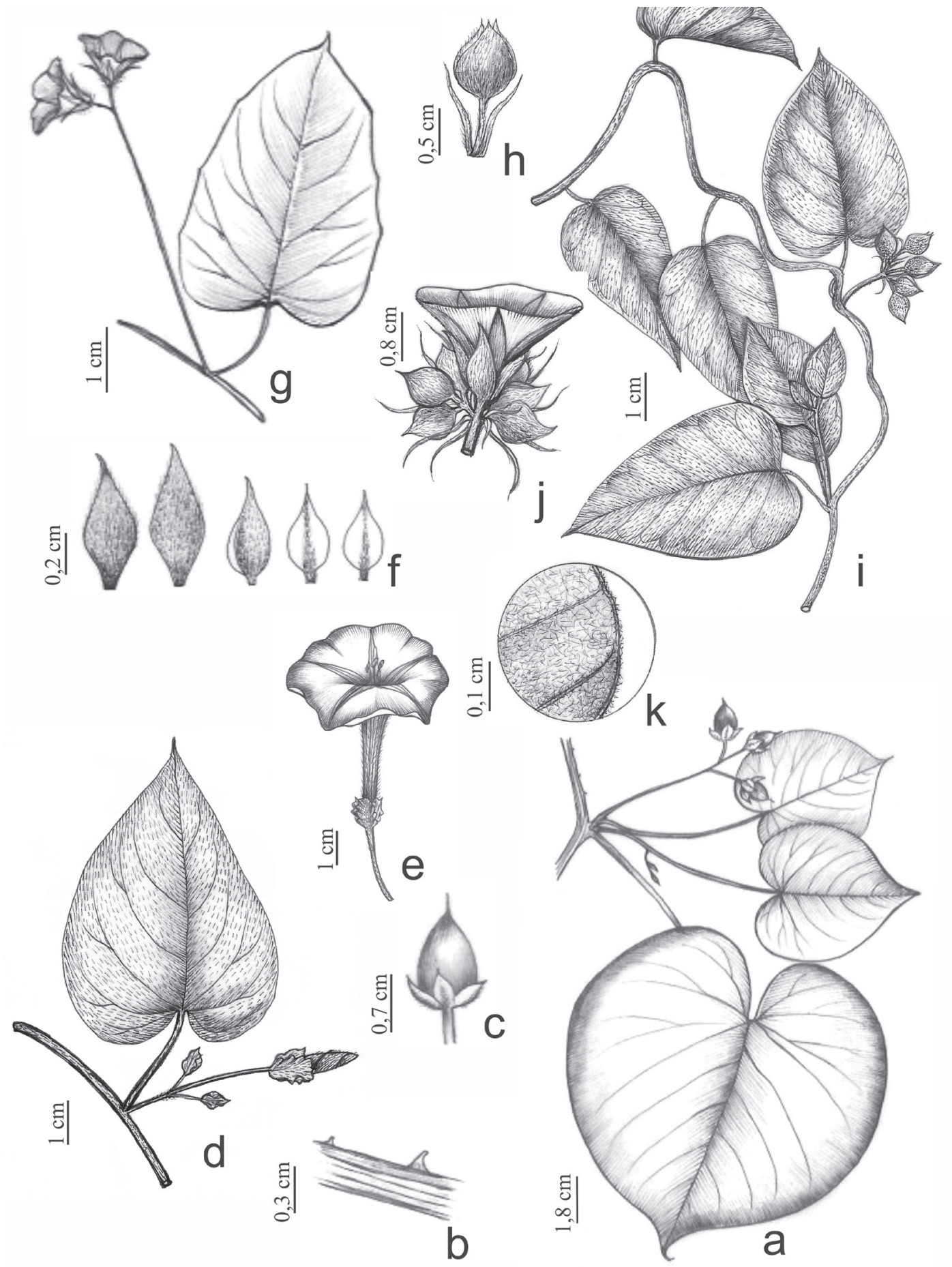

Figura 3. a-c. Ipomoea parasitica. a. Ramo fértil. b. Detalhe do caule com acúleos. c. Fruto. d-e. Ipomoea tubata. d. Ramo fértil. e. Flor. f-g. Jacquemontia corymbulosa. f. Sépalas externas à esquerda e internas à direita. g. Ramo fértil. h-k. Jacquemontia mucronifer. h. Botão com bractéolas. i. Ramo fértil. j. Inflorescência. k. Indumento foliar.

Figure 3. a-c. Ipomoea parasitica. a. Fertile branch. b. Detail of aculeate stem. c. Fruit. d-e. Ipomoea tubata. d. Fertile branch. e. Flower. f-g. Jacquemontia corymbulosa. f. Outer sepals (left), inner sepals (right). g. Fertile branch. h-k. Jacquemontia mucronifer. h. Bud with bracteoles. i. Fertile branch. j. Inflorescence. k. Leaf indumentum. 
margem inteira a sinuosa, discolores, face adaxial mais escura e glabrescentes e abaxial mais clara e velutina, 9-11 pares de veias secundárias, pecíolo 0,5-3 cm de compr. Inflorescência em cimeira, 3-flora, pedúnculo 1-4 cm compr., bractéolas elípticas, ca. $7 \times 2 \mathrm{~mm}$ compr., pubescentes, pedicelo $0,5-3 \mathrm{~cm}$ compr. Cálice com sépalas desiguais, externas ovadas, ca. 1,2 $\times 0,5 \mathrm{~cm}$, tomentosas, ápice arredondado, lisas, margem repanda, internas ovadas, ca. 1,5 $\times 0,7 \mathrm{~cm}$, tomentosas, ápice arredondado, lisas, margem repanda. Corola hipocrateriforme, ca. $6 \mathrm{~cm}$ de compr., pubescente, rosa. Estames, 1,7-2 cm compr., anteras ca. $5 \mathrm{~mm}$ compr. Estilete ca. $2 \mathrm{~cm}$ compr. Fruto deiscente. Sementes não vistas.

Material examinado: BRASIL. Pernambuco: Taquaritinga do Norte, 4-VI-1992, A.M. Miranda 492 (PEUFR).

Espécie endêmica do Brasil (Austin \& Huaman 1996), distribuída principalmente na região central do país, numa faixa que vai desde Rondônia até a Paraíba, se estendo ao Sudeste até o Estado de São Paulo (BFG 2015). Na área de estudo, foi coletada em Taquaritinga do Norte em Brejo de Altitude. Diferencia-se das demais espécies do gênero, encontradas na região, por apresentar corola hipocrateriforme, enquanto as demais apresentam corola infundibuliforme, além das sépalas com margem repanda muito distintas.

Jacquemontia Choisy, Mémoires de la Société de Physique et d'Histoire Naturelle de Genève 6(2): 476. 1834.

Geralmente trepadeiras herbáceas, raro lianas. Ramos com indumento variável, tricomas estrelados com 3 ramos, inermes. Folhas inteiras, glabrescentes, pubescentes ou velutinas. Inflorescência cimeira corimbiforme ou umbeliforme, 3-20 flora. Flores com pedicelos de ausentes a $11 \mathrm{~mm}$ compr., sépalas não acrescentes, iguais, subiguais ou desiguais, glabras a velutinas, lisas, sépalas com ápice reto, raro reflexo (J. martii). Corola infundibuliforme, lilás ou azul, raramente branca. Estames de tamanhos diferentes, 0,3-1 cm compr., anteras retas. Estilete inteiro, estigmas 2, ovais-planos. Fruto seco, geralmente globoso, deiscentes. Sementes glabras.

11. Jacquemontia corymbulosa Benth., The Botany of the Voyage of H.M.S. Sulphur 137. 1844[1845]. Figuras 3f-g

Liana. Ramos velutinos, entrenós $0,7-8,5 \mathrm{~cm}$ compr. Látex ausente. Folhas ovadas a lanceoladas,
2,7-12,5 × 1,3-7,5 cm, base cordada, ápice acuminado, margem discretamente sinuosa, velutinas, discolores com face adaxial mais escura, 6-8 pares de veias secundárias, pecíolo 0,3-5,6 cm compr. Inflorescência cimeira corimbiforme, 3-20-flora, pedúnculo 1,1-7,8 cm compr., bractéolas lineares, ca. $1 \mathrm{~cm}$ compr., pubescentes, pedicelo 0-0,3 mm compr. Cálice com sépalas desiguais, externas lanceoladas, ca. $7 \times 2 \mathrm{~mm}$, pubescentes, côncavas, ápice acuminado, lisas, internas ovadas, ca. $5 \times 2 \mathrm{~mm}$, tricomas restritos à porção central, côncavas, ápice acuminado, lisas. Corola 0,7-1 cm compr., glabra, azul. Estames 6-7 cm compr., anteras ca. $1 \mathrm{~mm}$ compr. Estilete ca. 6,5 $\mathrm{mm}$ compr. Fruto globoso ca. $4 \mathrm{~mm}$ compr. Sementes glabras, ca. $2 \mathrm{~mm}$ compr.

Material examinado: BRASIL. Pernambuco: Santa Cruz do Capibaribe, distrito do Pará, Serra do Pará, 24-IX-2014, M.T. Buril 1031 (PEUFR); Taquaritinga do Norte, 25-IX-2014, M.T. Buril 1056 (PEUFR).

Ocorre no Peru, Equador e no Brasil nos Estados da Bahia, Paraíba e Pernambuco, em áreas de Caatinga (sensu stricto) e Cerrado (sensu lato) (Buril 2013). Entretanto, no Alto Capibaribe, a espécie foi encontrada em áreas de Caatinga hiperxerófila e em áreas de Brejo. Pode ser confundida com J. pentanthos que também ocorre na área, diferenciando-se dessa por apresentar bractéolas lineares (vs. lanceoladas em $J$. pentanthos).

12. Jacquemontia mucronifera (Choisy) Hallier f., Botanische Jahrbücher für Systematik, Pflanzengeschichte und Pflanzengeographie 16: 543. 1893.

Figuras 3h-k

Trepadeira herbácea. Ramos velutinos, entrenós 0,9-7,5 cm compr. Látex ausente. Folhas lanceoladas, $1-3,5 \times 1,5-5,5 \mathrm{~cm}$, base cordada, ápice acuminado, mucronado, margem discretamente sinuosa, velutina em ambas faces, discolores com face adaxial ferrugínea mais escura, 7-9 pares de veias secundárias, pecíolo 0,4-2,5 cm compr. Inflorescência corimbiforme, ca. 16 flores, pedúnculo 1,1-6,5 cm compr., bractéolas setosas, 5-8 mm compr., pubescente, pedicelo ausente até $9 \mathrm{~mm}$ compr. Cálice com sépalas desiguais, externas lanceoladas, ca. $1 \times 0,3 \mathrm{~cm}$, pubescentes, ápice acuminado reto, e internas lanceoladas, ca. $5 \times 2 \mathrm{~mm}$, glabras, ápice acuminado. Corola ca. 1-1,3 cm compr., glabra, lilás. Estames 3-5 mm compr., anteras ca. $1 \mathrm{~mm}$ compr. Estilete $7 \mathrm{~mm}$ compr. Fruto globoso, ca. $5 \mathrm{~mm}$ compr. Sementes glabras, ca. $3 \mathrm{~mm}$ compr. 
Material examinado: BRASIL. Pernambuco: Santa Cruz do Capibaribe, distrito do Pará, Serra do Pará, 24-IX-2014, M.T. Buril 1030 (PEUFR); Taquaritinga do Norte, 25-IX-2014, M.T. Buril 1068 (PEUFR).

Espécie conhecida apenas no Brasil, desde o Ceará até o Paraná (BFG 2015) em áreas de Mata Atlântica, Cerrado e Caatinga (Buril 2013). Na região estudada, foi encontrada em Caatinga e Brejo de Altitude. Pode ser reconhecida pelas bractéolas setosas e pelo indumento foliar velutino, denso e de coloração ferrugínea. Geralmente é confundida com Jacquemontia pentanthos e J. corymbulosa. Contudo, diferencia-se destas duas pelo formato das bractéolas (lanceoladas em $J$. pentanthos e filiformes em $J$. corymbulosa) e pelo indumento das folhas (pubescentes em J. pentanthos).

13. Jacquemontia martii Choisy, Prodromus Systematis Naturalis Regni Vegetabilis 9: 398. 1845.

Figuras 4a-c

Trepadeira herbácea. Ramos pubescentes, entrenós 5,5-11 cm compr. Látex ausente. Folhas ovadas a lanceoladas, 5,5-7,7 × 2,5-5 cm, base cordada, raro arredondada, ápice acuminado, margem discretamente sinuosa, pubescentes, mais adensados na face abaxial, discolores com face adaxial mais escura, 7-8 pares de veias secundárias, pecíolo 1,7-3 cm compr. Inflorescência cimeira umbeliforme, 3-20-flora, pedúnculo 2,5-7 cm compr., bractéolas lineares, ca. $3 \mathrm{~mm}$ compr., pubescentes, pedicelo 8-11 mm compr. Cálice com sépalas iguais, lanceoladas, ca. $6 \times 2 \mathrm{~mm}$ compr., glabras, ápice acuminado reflexo. Corola 2-2,5 cm compr., glabra, azul. Estames 0,5-1 cm compr., anteras ca. $1 \mathrm{~mm}$ compr. Estilete 0,8-1 cm compr. Fruto globoso ca. $5 \mathrm{~mm}$ compr. Sementes glabras, ca. $3 \mathrm{~mm}$ compr.

Material examinado: BRASIL. Pernambuco: Taquaritinga do Norte, 25-IX-2014, M.T. Buril 1055 (PEUFR).

Espécie endêmica do Brasil, distribuída nas regiões Norte, Nordeste, Centro-Oeste e Sudeste (Buril 2013). No Alto Capibaribe, foi coletada apenas em Taquaritinga do Norte em área de Brejo com baixo impacto antrópico, e pode ser facilmente identificada pelas sépalas glabras com ápice reflexo.

14. Jacquemontia nodiflora (Desr.) G. Don., A General History of the Dichlamydeous Plants 4: 283. 1838.

Figuras 4d-e
Trepadeira herbácea. Ramos pubescentes, entrenós 2-5 cm compr. Látex ausente. Folhas lanceoladas a ovadas, 2-4 × 0,9-3 cm, base de cordada a arredondada, ápice de acuminado a emarginado, margem sinuosa, face adaxial glabrescente e abaxial pubescente, concolores, ca. 5 pares de veias secundárias, pecíolo 1-1,5 cm compr. Inflorescência cimeira corimbiforme, 6-8-flora, pedúnculo $0,1-1,2 \mathrm{~cm}$ compr., bractéolas lanceoladas, ca. $1 \mathrm{~mm}$ compr., pilosas, pedicelo 0,3-0,6 cm compr. Cálice com sépalas iguais, ca. $3 \times 2 \mathrm{~mm}$, rotundas, ápice arredondado, pubescentes. Corola 1-1,5 cm, glabra, branca. Estames ca. $6 \mathrm{~mm}$ compr., anteras ca. $1 \mathrm{~mm}$ compr. Estilete ca. 1,2 mm compr. Fruto globoso, ca. $5 \mathrm{~mm}$ compr. Sementes glabras, ca. 1,5 mm compr.

Material examinado: BRASIL. Pernambuco: Santa Cruz do Capibaribe, Distrito do Pará, Serra do Pará, 24-IX-2014, M.T. Buril 1032 (PEUFR).

Material adicional: BRASIL. Pernambuco: Parnamirim, 14-XII-1988, M.L. Guedes 1611 (PEUFR).

Ocorre desde o México até o Brasil, em vegetação de Caatinga e de Cerrado, entretanto, há maior predominância dessa espécie no primeiro tipo vegetacional (Buril 2013). No Brasil, é registrada em todo o Nordeste, com exceção do Maranhão, Goiás, Espírito Santo, Minas Gerais e Rio de Janeiro. Na região estudada, é pouco frequente e está comumente associada à vegetação de Caatinga. É facilmente diferenciada das demais espécies do gênero ocorrentes na área, pelas sépalas de ápice arredondado.

\section{Jacquemontia pentanthos (Jacq.) G. Don., A}

General History of the Dichlamydeous Plants 4:

283 Gen. Hist. 4: 283. 1838.

Figura 4f

Trepadeira herbácea. Ramos pubescentes, entrenós 1,5-7,5 cm compr. Látex ausente. Folhas ovadas a cordadas, $4-7,3 \times 3-5 \mathrm{~cm}$, base cordada, ápice acuminado, raro arredondado, margem discretamente sinuosa a inteira, pubescente, tricomas mais adensados na face abaxial, discolores com face adaxial mais escura, 4-6 pares de veias secundárias, pecíolo 1,1-3 cm compr. Inflorescência cimeira umbeliforme, 5-11-flora, pedúnculo 1,5-12,7 cm compr., bractéolas lanceoladas, ca. $1 \mathrm{~cm}$ compr., pubescentes, pedicelo ausente a ca. $1 \mathrm{~mm}$ compr. Cálice com sépalas desiguais, externas lanceoladas, ca. $7 \times 2 \mathrm{~mm}$, pubescentes, ápice acuminado reto, internas lanceoladas, ca. $4 \times 1 \mathrm{~mm}$, 


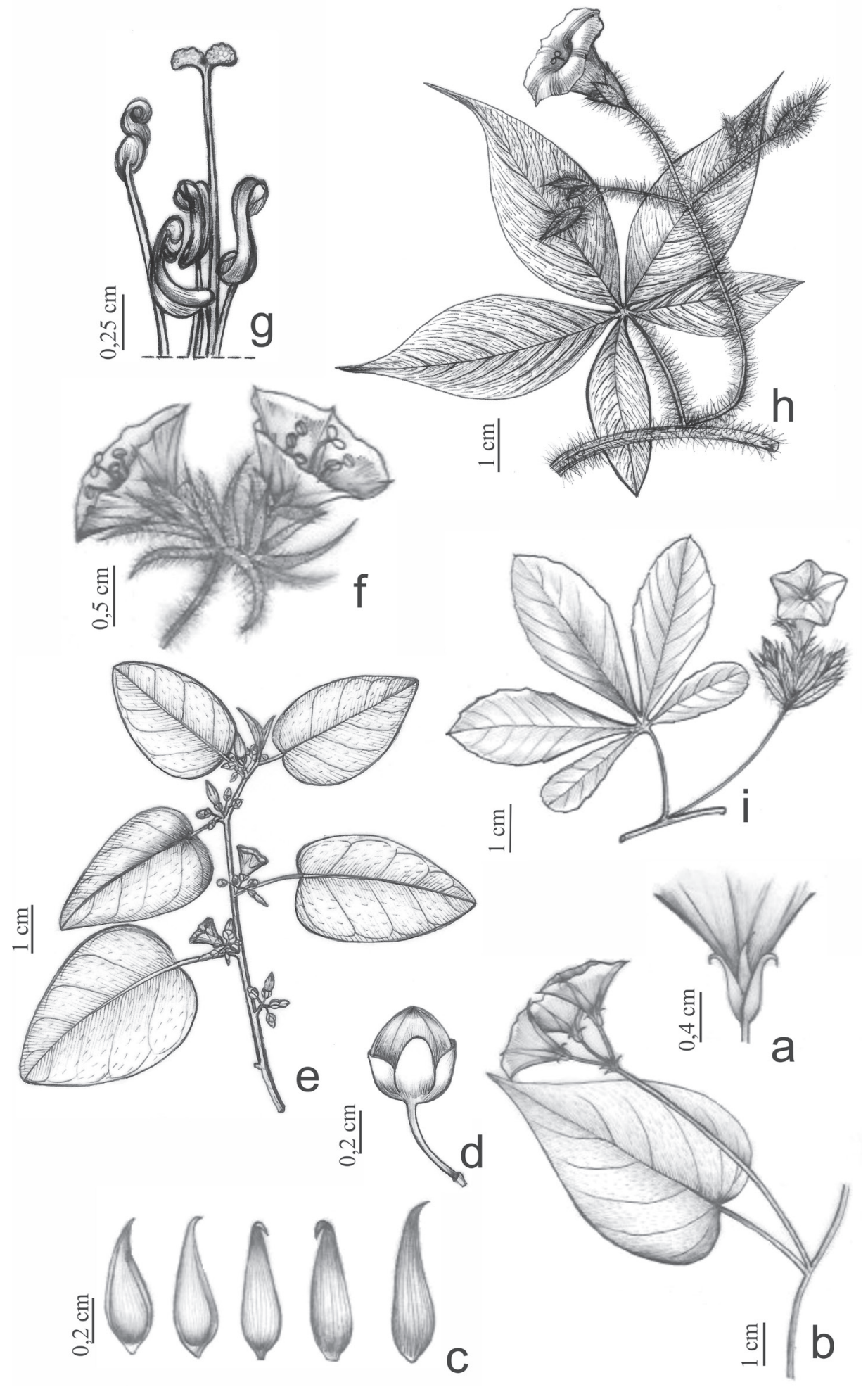

Figura 4. a-c. Jacquemontia martii. a. Vista lateral do cálice. b. Ramo fértil. c. Sépalas internas à esquerda e externas à direita. d-e. Jacquemontia nodiflora. d. Fruto. e. Ramo fértil. f. Jacquemontia pentanthos. Inflorescência. g-h. Merremia aegyptia. g. Anteras e estilete. h. Ramo fértil. i. Merremia cissoides. Ramo fértil.

Figure 4. a-c. Jacquemontia martii. a. Lateral view of calyx. b. Fertile branch. c. Inner sepals (left), outer sepals (right). d-e. Jacquemontia nodiflora. d. Fruit. e. Fertile branch. f. Jacquemontia pentanthos. Inflorescence. g-h. Merremia aegyptia. g. Anthers and style. h. Fertile branch. i. Merremia cissoides. Fertile branch. 
pubescentes, ápice acuminado. Corola 1,1-1,3 cm compr., glabra, lilás. Estames 5-8 cm compr., anteras 0,5-1 mm compr. Estilete $7 \mathrm{~mm}$ compr. Fruto globoso, ca. $5 \mathrm{~mm}$ compr. Sementes glabras, ca. $3 \mathrm{~mm}$ compr.

Material examinado: BRASIL. Pernambuco: Taquaritinga do Norte, 25-IX-2014, M.T. Buril 1062 (PEUFR); Taquaritinga do Norte, 25-IX-2014, M.T. Buril 1064 (PEUFR).

Presente desde os Estados Unidos até a Argentina. No Brasil ocorre nas regiões Norte, Nordeste, Centro-Oeste e Sudeste (Buril 2013). Frequente em Taquaritinga do Norte. Pode ser confundida com $J$. corymbulosa e $J$. mucronifer como já foi referido na descrição destas espécies.

Merremia Dennst. ex Endl., Gen. Pl. 18: 1403. 1841.

Trepadeiras herbáceas. Ramos inermes, lisos, glabrescentes a pubescentes, tricomas simples. Folhas compostas, digitadas, 5-folioladas, glabras a pubescentes. Inflorescência em cimeira ou flores solitárias, 1-18 flora. Flores com pedicelos ausentes a $4 \mathrm{~cm}$ compr., sépalas raro acrescentes, subiguais ou desiguais, glabras a hirsutas, lisas, com ápice reto ou reflexo. Corola infundibuliforme, frequentemente branca, raro com fauce do tubo vinácea. Estames de tamanhos diferentes, 1,2-2 cm compr., anteras retorcidas após antese. Estilete inteiro, estigmas 2, globosos. Fruto seco, globoso ou quadrangular, deiscente.

\section{Merremia aegyptia (L.) Urb., Genera Plantarum}

18: 1403.1841.

Figuras 4g-h

Trepadeira herbácea. Ramos hirsutos, entrenós 8,7-11,2 cm compr. Látex ausente. Folhas digitadas $\mathrm{n}$-folioladas; folíolos lanceolados, 1,5-6,9 × 0,6-2,7 cm, base atenuada, ápice agudo, margem ciliada e discretamente sinuosa, pubescentes, tricomas mais adensados na face adaxial, 9-10 pares de veias secundárias, sésseis, pecíolo 1-2,7 cm compr., não alado. Inflorescência cimeira 3-6-flora, pedúnculo 4,5-5,5 cm compr., bractéolas lineares, ca. $2 \mathrm{~mm}$ compr., pubescentes, pedicelo 0,7-2,5 $\mathrm{mm}$ compr. Cálice com sépalas desiguais, externas lanceoladas, ca. 1,5-2 × 0,5-0,7 cm, hirsutas, ápice acuminado, reflexo, lisas, internas lanceoladas, ca. 9-10 × 5-6 mm, glabras, ápice acuminado mucronado, não acrescentes. Corola 1,8-2 cm compr., glabra, branca. Estames 1,2-1,5 cm compr., anteras ca. $5 \mathrm{~mm}$ compr. Estilete $1 \mathrm{~cm}$ compr. Frutos globosos, ca. 1,5 cm compr. Sementes não observadas.
Material examinado: BRASIL. Pernambuco: Santa Cruz do Capibaribe, 25-IX-2014, M.T. Buril 1072 (PEUFR).

Material adicional: BRASIL. Pernambuco: Ibimirim, 30-VI-1995, K. Andrade 103 (PEUFR).

Amplamente distribuída nas Américas e, no Brasil, não é registrada apenas para região Sul (BFG 2015). Foi encontrada em área antrópica na microrregião do Alto Capibaribe. Merremia aegyptia é facilmente diferenciada das demais espécies do gênero pelos ramos e folhas hirsutos.

17. Merremia cissoides (Lam.) Hallier f., Botanische Jahrbücher für Systematik, Pflanzengeschichte und Pflanzengeographie 16(4-5): 552. 1893.

Figura 4i

Trepadeira herbácea. Ramos pubescentes, entrenós 2,5-10 cm compr. Látex ausente. Folhas digitadas n-folioladas; folíolos lanceolados, $1,1-5,1 \times 0,4-2,2 \mathrm{~cm}$, base cuneada, ápice agudo, mucronado, margem denteada e ciliada, glabrescentes, discolores com face adaxial mais escura, 6-7 pares de veias secundárias, sésseis, pecíolo 1-4 cm compr., não alado. Inflorescência em monocásio ou flor solitária, 3-4-flora, pedúnculo 0,3-4,2 cm compr., bractéolas lanceoladas, ca. 1-2 cm compr., glabrescentes, pedicelo 0-1,5 mm compr. Cálice com sépalas iguais, lanceoladas, 1,1-1,5 × 0,2-0,4 cm, pubescentes, ápice acuminado, retos, não acrescentes. Corola $2,5-3 \mathrm{~cm}$ compr., glabra, branca com fauce do tubo vinácea. Estames 1,3-1,7 cm compr., anteras 0,4-0,5 cm compr. Estilete ca. 1,5 mm compr. Frutos e sementes não observados.

Material examinado: BRASIL. Pernambuco: Taquaritinga do Norte, 25-IX-2014, M.T. Buril 1070 (PEUFR).

Espécie distribuída nas Américas, desde o México até a Argentina (Ferreira \& Miotto 2013). Amplamente distribuída em todas as regiões brasileiras (BFG 2015). No Alto Capibaribe, foi encontrada em região de Brejo e pode ser facilmente diferenciada de $M$. aegyptia pelo indumento pubescente e margem das folhas serreada (vs. tricomas hirsutos e margem denteada e ciliada e discretamente sinuosa).

18. Merremia macrocalyx (Ruiz \& Pav.) O’Donell, Lilloa 6 (2): 506-511. 1941.

Figuras 5a-c

Trepadeira herbácea. Ramos glabrescentes, entrenós 8-10,5 cm compr. Látex ausente. Folhas 


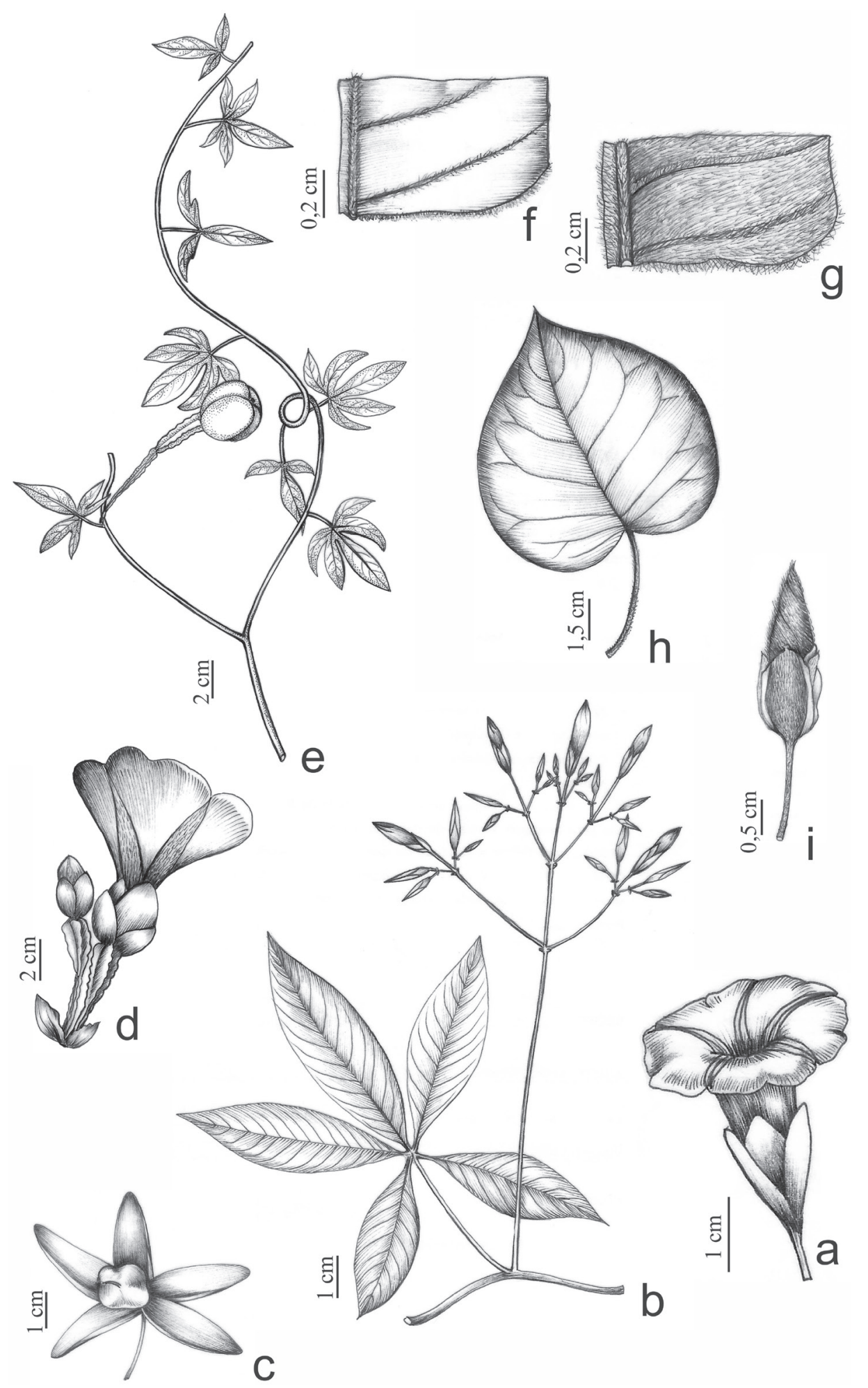

Figura 5. a-c. Merremia macrocalyx. a. Vista lateral da flor. b. Ramo fértil. c. Fruto com sépalas acrescentes. d-e. Operculina macrocarpa. d. Flor. e. Hábito. f-i. Turbina cordata. f. Face adaxial da folha. g. Face abaxial da folha. h. Folha. i. Botão.

Figure 5. a-c. Merremia macrocalyx. a. Lateral view of flower. b. Fertile branch. c. Fruit with accrescent sepals. d-e. Operculina macrocarpa. d. Flower. e. Habit. f-i. Turbina cordata. f. Adaxial leaf surface. g. Abaxial leaf surface. h. Leaf. i. Bud. 
digitadas n-folioladas; folíolos oblanceolados, 2-8 $\times 1-4 \mathrm{~cm}$, base cuneada, ápice acuminado, mucronado, margem sinuosa, glabra, discolores com face adaxial mais escura, 10-14 pares de veias secundárias, pecíolo $3,5-4,5 \mathrm{~cm}$ compr., não alado. Inflorescência em cimeira, 10-18-flora, pedúnculo 7-10,5 cm compr., bractéolas ausentes. Cálice com sépalas subiguais, externas elípticas, $1,4 \times 0,7 \mathrm{~cm}$, glabras, ápice arredondado, lisas, acrescentes, internas elípticas, ca. 2,1 $\times 1 \mathrm{~cm}$, glabras, ápice arredondado, lisas, acrescentes. Corola ca. $4 \mathrm{~cm}$ compr., glabra, branca. Estames 1,5-2 cm compr., anteras 3-6 mm compr. Estilete ca. $2 \mathrm{~cm}$ compr. Fruto quadrangular, ca. $2 \mathrm{~cm}$ compr. Sementes velutinas, ca. $3 \mathrm{~mm}$ compr.

Material examinado: BRASIL. PernambUco: Vertentes, 21-IV-2015, N. Brasil 5 (PEUFR).

Material adicional: BRASIL. Pernambuco: Bonito, 1-VIII-2001, A.G. Silva 479 (PEUFR).

Ocorre dos Estados Unidos até a Argentina (Ferreira \& Miotto 2013). No Brasil, é referida para todos os Estados, excetuando Piauí e Rio Grande do Sul (BFG 2015). No Alto Capibaribe, foi coletada na borda de mata em área de Brejo de Altitude. Pode ser reconhecida pelas sépalas longas (ca. $1 \mathrm{~cm}$ compr.), glabras e que são acrescentes nos frutos.

19. Operculina macrocarpa (L.) Urb., Symbolae Antillanae seu Fundamenta Florae Indiae Occidentalis 3: 343. 1902.

Figuras 5d-e

Liana. Ramos glabros, inermes, entrenós 8-14 cm compr. Látex leitoso. Folhas digitadas, 5-folioladas, lanceoladas, 2,5-8 × 1-3,2 cm, base cuneada, ápice agudo, levemente sinuosa, glabrescente em ambas faces, concolores, 10-12 pares de veias secundárias, pecíolo 3-5 cm compr., alado. Inflorescência em cimeira, 1-2-flora, pedúnculo 7-8 cm compr., bractéolas oblongas, $0,8-1,2 \mathrm{~cm}$ compr., glabras, pedicelo 1,5-3 cm compr. Cálice com sépalas iguais, rotundas, ca. 2,5 ×2,6 cm, glabras, ápice arredondado, lisas. Corola infundibuliforme ca. $8 \mathrm{~cm}$ compr., pubescente nas nervuras mesopétalas, branca. Estames de tamanhos diferentes, ca. $4 \mathrm{~cm}$ compr., anteras retorcidas após a antese, ca. $5 \mathrm{~mm}$ compr. Estilete inteiro, ca. $6 \mathrm{~mm}$ compr, estigmas 2, globosos. Frutos cápsulas operculadas, globosos, deiscentes, ca. $2 \mathrm{~cm}$ compr. Sementes glabras, ca. $8 \mathrm{~mm}$ compr.

Material examinado: BRASIL. PernAmBuco: Vertentes, 30-X-1941, L.P. Xavier JPB430 (JPB).
Material adicional: BRASIL. Pernambuco: Santa Maria da Boa Vista, 3-V-1971, E.P. Heringer 469 (PEUFR); Santa Maria da Boa Vista, 4-V-1971, T. Ramos 17 (PEUFR); Afrânio, 23-IV-1971, E.P. Heringer 301 (PEUFR). BAHIA: Jequié, 23-IV-2004, G.E.L. Macedo 751 (PEUFR).

No Brasil ocorre em quase todos os Estados do Nordeste, em todo Sudeste, nos Estados de Goiás até Paraná, além do Distrito Federal (BFG 2015). Assim como Merremia, apresenta anteras retorcidas, mas são facilmente diferenciadas pelos pedúnculos e pedicelos alados (vs. lisos em Merremia).

20. Turbina cordata (Choisy) D.F. Austin \& Staples, Journal of the Arnold Arboretum 64: 488. 1983. Figuras $5 f-i$

Trepadeira. Ramos vilosos, tricomas simples, inermes, entrenós 2-6,5 cm compr. Látex não observado. Folhas simples, cordadas, 3-9 $\times 2-8 \mathrm{~cm}$, base cordada, ápice acuminado, mucronado, margem ciliada, levemente sinuosa, face adaxial glabrescente, com tricomas restritos às nervuras, face abaxial densamente vilosa, discolores com face adaxial mais escura, 7-9 pares de veias secundárias, pecíolo 2,5-4,5 cm compr. Inflorescência em cimeira, 10-16-flora, pedúnculo 4-10 cm compr., bractéolas lanceoladas, 0,8-1,5 cm compr., face abaxial pubescente e adaxial glabra, pedicelo 0,3-1,5 cm compr. Cálice com sépalas iguais, ovadas, ca. 1,2 ×0,8 cm, velutinas, ápice arredondado mucronado, lisas, margem inteira. Corola infundibuliforme 5,2-6,7 cm, pubescente, lilás a rósea. Estames de tamanhos diferentes, ca. $4 \mathrm{~cm}$ compr., anteras retas, ca. $5 \mathrm{~mm}$ compr. Estilete ca. $7 \mathrm{~mm}$ compr,, estigma 2 globosos. Frutos elipsoides, secos, indeiscentes, ca. 1,5 cm compr. Sementes não observadas.

Material examinado: BRASIL. Pernambuco: Taquaritinga do Norte, 18-IV-1997, V. Santos 2 (PEUFR).

Material adicional: BRASIL. Pernambuco: Fazenda Nova, 11-VIII-1998, L.S. Figuerêdo 415 (PEUFR).

Espécie endêmica do Brasil, com ampla distribuição no país (BFG 2015). Bastante similar a Ipomoea, distingue-se das demais espécies por apresentar folhas com indumento glabrescente com tricomas restritos às nervuras na face adaxial, e face abaxial com indumento densamente viloso, além do fruto indeiscente. 


\section{Literatura Citada}

Andrade, G.O., Lins, R.C. 1965. Introdução a morfoclimatologia do nordeste do Brasil. In: Arquivos do Instituto de Ciências da Terra, Recife, n. 3-4, pp. 17-28.

Austin, D.F. 1998. Convolvulaceae. Morning Glory family. Journal of the Arizona-Nevada Academy of Science 30: 61-83.

Austin, D.F. 2004. Convolvulaceae. In: N.P. Smith, S.A. Mori, A. Henderson, D.W. Stevenson \& S.V. Heald (eds.). Flowering plants of the Neotropics. New York Botanical Garden, Princeton University Press, Princeton, pp. 113-115.

Austin, D.F. \& Huaman, Z. 1996. A synopsis of Ipomoea (Convolvulaceae) in the Americas. Taxon 45: 3-38.

BFG - Brazil Flora Group. 2015. Growing knowledge: an overview of Seed Plant diversity in Brazil. 66: 1085-1113.

Buril, M.T. 2013. Sistemática e Filogenia de Jacquemontia (Choisy) Convolvulaceae. Tese de Doutorado, Universidade Federal de Pernambuco, Recife.

Buril, M.T. \& Alves, M. 2011a. Flora da Usina São José, Igarassu, Pernambuco: Convolvulaceae. Rodriguésia 62: 93-105.

Buril, M.T. \& Alves, M. 2011b. A new species of Jacquemontia (Convolvulaceae) from Northeastern Brazil. Brittonia (Bronx, N.Y.) 63: 436-441.

Buril, M.T. \& Alves, M. 2012a. Jacquemontia macrocalyx (Convolvulaceae), a New Species Endemic to Espinhaço Range, Brazil. Novon (Saint Louis, Mo.) 22: 137-140.

Buril, M.T. \& Alves, M. 2012b. Two new species of Jacquemontia Choisy (Convolvulaceae) endemic to Bahia, Brazil. Phytotaxa 69: 27-32.

Buril, M.T. \& Alves, M. 2013. Jacquemontia diamantinensis sp. nov. (Convolvulaceae) from the Chapada Diamantina, Brazil. Nordic Journal of Botany 31: 603-606.

Buril, M.T., Simão-Bianchini, R. \& Alves, M. 2012. Jacquemontia robertsoniana (Convolvulaceae), a new shrub species from Brazil. Kew Bulletin 67: 55-459.

Buril, M.T., Delgado, G., Barbosa, M.R.V. \& Alves, M. 2013. Convolvulaceae da Região do Cariri Paraibano. Revista Nordestina de Biologia 21: 3-26.

Chaves, D.P. 2009. Intoxicação experimental por Ipomoea asarifolia em ovinos: achados clínicos, laboratoriais e anatomopatológicos. Tese de Doutorado, Universidade Estadual Paulista, São Paulo.

CONDEPE/FIDEM. 2006. Bacia Hidrográfica do Rio Una, GL 4 E GL 5. Série Bacias Hidrográficas de Pernambuco n. 3. Agência Estadual de Planejamento e Pesquisas de Pernambuco, Recife.
CPRM. 2005. Serviço Geológico do Brasil. Projeto Cadastro de Fontes de Abastecimento por Água Subterrânea do Estado de Pernambuco. Relatórios dos Municípios de Taquaritinga do Norte, Casinhas, Santa Cruz do Capibaribe, Toritama, Frei Miguelinho, Santa Maria do Cambucá, Vertentes do Lério e Surubim. Companhia de Pesquisa de Recursos Minerais, Recife.

Delgado, G. Buril, M.T. \& Alves, M. 2014. Convolvulaceae do Parque Nacional do Catimbau, Pernambuco, Brasil. Rodriguésia 65: 261-278.

Ferreira, P.P.A. \&, Miotto, S.T.S. 2013. O gênero Merremia (Convolvulaceae) na Região Sul do Brasil. Rodriguésia 64: 635-646.

Gotardo, A.T. 2009. Avaliação da toxicidade da Ipomoea carnea em caprinos durante o período perinatal: estudos de neuroteratologia. Tese de Doutorado, Universidade de São Paulo, São Paulo.

Harris, J.G., Harris, M.W. 2001. Plant identification Terminology: an Illustrated glossary. 2 ed. Spring Lake, Utah.

Mabberley, D.J. 1987. The plant book. 2 ed. Cambridge University press, Cambridge.

Mori, S.A., Mattos-Silva, L.A., Lisboa, G. \& Coradin, L. 1985. Manual de manejo do herbário fanerogâmico. 24 ed. Centro de Pesquisas do Cacau, Ilhéus.

Pereira, W. 1998. Prevenção e controle da parasita Cuscuta em áreas cultivadas com hortaliças. EMBRAPA-CNPH (Comunicado Técnico da Embrapa Hortaliças, 9), Brasília.

Silva, C.V. \& Simão-Bianchini, R. 2012. Introdução à Sistemática de Convolvulaceae. Desenvolvimento de material didático ou instrucional - Apostila. Disponivel em http://www.biodiversidade.pgibt.ibot.sp.gov.br/Web/ pdf/Introducao_a_Sistematica_de_Convolvulaceae Cintia_Vieira_da_Silva.pdf (acesso em 04-V-2016).

Silva, C.V. \& Simão-Bianchini, R. 2014. Three new species of Evolvulus (Convolvulaceae) from Bahia, Brazil. Phytotaxa 166: 132-138.

Simão-Bianchini, R. 1998. Ipomoea L. (Convolvulaceae) no Sudeste do Brasil. Tese de Doutorado, Universidade de São Paulo, São Paulo.

Simão-Bianchini, R., Ferreira, P.P.A., Pastore, M. 2015. Convolvulaceae. Lista de Espécies da Flora do Brasil. Jardim Botânico do Rio de Janeiro. Disponível em http://www.floradobrasil.jbrj.gov.br/jabot/floradobrasil/ (acesso em 17-III-2016).

Souza, V.C. \& Lorenzi, H. 2005. Botânica sistemática. 3 ed. Instituto Plantarum de Estudos da Flora, Nova Odessa.

Staples, G.W. 2012. Convolvulaceae Unlimeted. Disponível em http://convolvulaceae.myspecies.info/ (acesso em 22-I-2015).

Staples, G.W. \& Brummitt, R.K. 2007. Convolvulaceae. In: V.H. Heywood, R.K. Brummitt, A. Culham, \& O. Seberg (eds.). Flowering plant families of the world. Royal Botanic Gardens, Kew, pp. 108-110. 